\title{
DETERMINASI NILAI PERUSAHAAN MELALUI PROFITABILITAS : Studi Pada Bank Umum Syariah di Indonesia
}

\author{
Andi Sultan¹, Arung Gihna Mayapada², Muhammad Darma Halwi3, Jurana4, \\ Muhammad Syafaat ${ }^{5}$ \\ 1,2,3,4,Jurusan Akuntansi, Fakultas Ekonomi dan Bisnis, Universitas Tadulako, Palu, email : \\ arunggihna@gmail.com \\ 5,Jurusan Perbankan Syariah, Fakultas Ekonomi dan Bisnis Islam, UIN Datokarama Palu \\ email : Muhammad.syafaat@iainpalu.ac.id
}

ABSTRACT

Penelitian ini bertujuan untuk menguji dan menganalisis pengaruh pembiayaan mudharabah, murabahah dan musyarakah terhadap nilai perusahaan dengan perofitabilitas sebagai variabel intervening. Penelitian ini menggunakan pendekatan kuantitatif. Sampel penelitian ini adalah bank umum syariah yang terdaftar di Bank Indonesia (BI) dan Otoritas Jasa Keuangan (OJK) yang mana berjumlah lima dengan periode penelitian 2013-2020. Metode analisis data yang digunakan adalah teknik analisis jalur (path analysis). Hasil penelitian ini menunjukan ada pengaruh parsial signifikan pembiayaan mudharabah dan musyarakah terhadap profitabilitas sementara pembiyaan murabahah tidak berpengaruh signifkan terhadap profitabilitas. Sedangkan ini juga mengungkap profitabilitas berpengaruh parsial signifikan terhadap nilai perusahaan sedangkan pembiyaan mudharabah, murabahah, musyarakah tidak berpengaruh signifikan terhadap nilai perusahaan. Pembiayaan mudharabah dan murabahah memiliki pengaruh secara signifikan terhadap nilai perusahaan melalui profitabilitas dan pembiayaan musyarakah tidak memiliki pengaruh terhadap nilai perusahaan melalui perofitabilitas.
INFORMASI

ARTIKEL

Katakunci:

Pembiayaan

Mudharabah, Murabahah, Musyarakah, Nilai

Perusahaan,

Profitabilitas 


\section{PENDAHULUAN}

Beberapa dekade terakhir kegiatan perbankan atau entitas yang bergerak di bidang pasar modal, dana pensiun dan lain sebagainya yang berbasis syariah mengalami peningkatan pesat. Perkembangan pesat terutama dapat dilihat dari peningkatan jumlah bank atau kantor yang menerepakan prinsip syariah diikuti dengan peningkatan jumlah aset yang mereka kelola. Sejak dikembangkannya sistem perbankan syariah di Indonesia, perkembangan keuangan syariah di Indonesia sudah banyak mencapai kemajuan, baik dari aspek kelembagaan dan perangkat regulasi yang diterapkan, infrastruktur penunjang dan sistem pengawasan maupun awareness atau literasi masyarakat terhadap layanan jasa keuangan syariah. Bahkan sistem keuangan syariah di Indonesia sudah menjadi salah satu sistem terbaik dan terlengkap yang diakui secara internasional berdasarkan peringkat Islamic Finance Development Indicator (IFDI) yang mana Indonesia berada pada posisi keuangan syariah terbaik ke empat pada tahun 2019 hingga pada tahun 2020 Indonesia menempati posisi kedua.

Saat ini perbankan syariah atau biasa dikenal Bank Umum Syariah (BUS) di Indonesia mengalami peningkatan yang signifikan seiring dengan berkembangnya pemikiran masyarakat tentang bank syariah yang tanpa bunga (riba). Hal ini dibuktikan dengan peningkatan jumlah bank syariah di Indonesia pada tahun 2020 yaitu menjadi 14 Bank Umum Syariah (BUS) yang beroperasi dengan 162 kantor cabangnya yang mana kesemuanya terdaftar pada Otoritas Jasa Keuangan (OJK). Bank Umum Syariah (BUS) adalah bank yang beroperasi sesuai dengan prinsip-prinsip syariah yang mana berbeda dengan bank prinsip konvensional. Pada intinya prinsipbank syariah tersebut mengacu kepada syariah agama Islam yang berpedoman utama kepada Al Quran, hadist, dan ijma ulama. Selain itu operasionalisasi perbankan syariah di Indonesia merujuk pada Bank Indonesia (BI), Otoritas Jasa Keuangan (OJK), dan Dewan Syariah Nasional Majelis Ulama Indonesia (DSN-MUI).

Bank Umum Syariah (BUS) menjadi entitas yang dimana berfungsi sebagai lembaga perantara keuangan (financial intermediary) dengan tujuan menghimpun dana masyarakat yang kelebihan dana (surplus unit) dan kemudian menyalurkannya kepada pihak-pihak yang kekurangan dana (deficit unit). Salah satu cara yang dilakukan untuk menyalurkan dana tersebut oleh bank umum syariah melalui pembiayaan. Pembiayaan yang sering digunakan oleh bank syariah pada tahun 2020 berdasarkan data Statistik Perbankan Syariah (SPS) yang diterbitkan oleh Otoritas Jasa Keuangan (OJK) meliputi pembiayaan mudharabah yang mana menyalurkan dananya kepada nasabah untuk menjalankan unit usaha yang telah disepakati, dan pembiayaan murabahah yaitu merupakan pembiayaan untuk pengadaan suatu barang yang kemudian dijual kembali untuk mendapatkan keuntungan (margin) serta pembiayaan musyarakah yaitu bentuk kerja sama dua pihak atau lebih yang masing-masing memberikan kontribusi dan resiko ditanggung berdasarkan kesepakatan.

Pembiayaan yang kurang baik disebabkan oleh adanya resiko bisnis yang dihadapi nasabah dalam menerima pembiayaan dari bank syariah dan juga resiko yang terdapat pada bank syariah itu sendiri. Risiko pembiayaan bank syariah yang dihadapi tidak selalu mudah teridentifikasi sehingga dapat menyebabkan peningkatan pembiayaan bermasalah atau non performing financing (NPF). Penurunan pembiayaan bermasalah 
atau non performing financing (NPF) dan laba (pendapatan) pada bank syariah akan berpengaruh terhadap nilai perusahaan karena perolehan laba dalam satu periode dapat menjadi sinyal bagi investor dalam berinvestasi. Earning Per Share (EPS) adalah rasio laba per lembar saham atau di sebut juga dengan nilai buku dengan tujuan untuk mengukur keberhasilan manajemen dalam mencapai keuntungan bagi para pemegang saham ${ }^{1}$. Semakin tinggi EPS maka semakin tinggi kepercayaan pasar akan prospek perusahaan. EPS adalah bentuk pembagian keuntungan yang berikan kepada para pemegang saham dari setiap lembar saham yang di miliki. Semakin tinggi EPS dapat diartikan bahwa perusahan telah berhasil menciptakan nilai bagi pemegang saham (investor) ${ }^{2}$.

\section{TINJAUAN PUSTAKA}

\subsection{Bank Umum Syariah (BUS)}

Bank syariah pada dasarnya adalah entitas yang bergerak untuk menghimpunan dana dari masyarakat dan kemudian di salurkan kembali dalam bentuk pembiayaan. Sistem perbankan di indonesiasistem terdapat dua macam sistem operasional, yaitu perbankan konvensional dan syariah. Bank syariah adalah unit yang menjalankan kegiatan operasionalnya berdasarkan prinsip syariah dan menurut jenisnya terdiri atas Bank Umum Syariah (BUS), Unit Usaha Syariah (USS), dan Bank Pembiayaan Rakyat Syariah (BPRS). ${ }^{3}$

${ }^{1}$ Kasmir. (2014). Analisis Laporan Keuangan. Edisi Pertama. Cetakan Ketujuh. Pt Raja Grafindo Persada.

2 Fahmi. (2015). Manajemen Investasi, Teori Dan Soal Jawab. Edisi Kedua. Salemba Empat. Jakarta.

${ }^{3}$ Undang-Undang No. 21 tahun 2008 tentang Perbankan Syariah

\subsection{Pembiayaan Bank Syarih}

Pembiayaan merupakan salah satu tugas pokok bank, yaitu pemberian fasilitas dana untuk memenuhi kebutuhan nasabahnya, istilah pembiayaan lahir dari kata I velive, I trust yang artinya "saya percaya" yang berarti bank selaku shahibul mal menaruh kepercayaan kepada nasabahnya untuk menjalankan amanah yang telah diberikan bank selaku penyedia dana. Dana tersebut harus digunakan dengan benar dan adil berdasarkan syaratsyarat yang telah disepakati bersama. Pembiayaan pada dasarnya diberikan atas dasar kepercayaan. Dengan demikian, pemberian pembiayaan adalah pemberian kepercayaan. Hal ini berarti prestasi yang diberikan benarbenar harus diyakini dapat dikembalikan oleh penerima pembiayaan sesuai dengan waktu dan syarat-syarat yang telah disepakati bersama ${ }^{4}$.

\subsection{Pembiayaan Mudharabah}

Mudharabah adalah akad perjanjian antara kedua belah pihak, yang salah satu dari keduanya memberi modal kepada yang lain supaya dikembangkan, sedangkan keuntungannya dibagi antara keduanya sesuai dengan ketentuan yang disepakati. Mudharabah dalam fatwa dewan syariah nasional majelis ulama indonesia NO:115/DSN-MUI/IX/2017, merupakan kerja sama antara pemilik modal (malik/shahib al-mal) yang menyediakan seluruh modal dengan pengelola (amil/mudharib) dan keuntungan usaha dibagi di antara mereka sesuai nisbah yang desepakati dalam akad.

4 Abdul Jalil \& Sitti Azizah Hamzah. (2020). Pengaruh bagi hasil dan kebutuhan modal terhadap minat UMKM mengajukan pembiayaan pada Lembaga keuangan syariah di Kota Palu. Jurnal Ilmu Perbankan dan Keuangan Syariah, 2(2), 188. 
Bentuk ini menegaskan kerja sama dengan kontribusi seratus persen modal dari pemilik modal dan keahlian mengelola keuangan dari pengelola.

Landasan Hukum Mudharabah

Quran Surah Al-Maidah (5):2

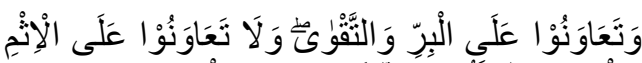

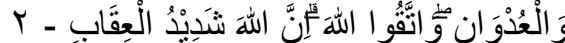

Terjemahannya :

Dan tolong-menolonglah kamu dalam (mengerjakan) kebajikan dan takwa, dan jangan tolong-menolong dalam berbuat dosa dan permusuhan. Bertakwalah kepada Allah, sungguh, Allah sangat berat siksaan-Nya ${ }^{5}$.

Tafsir ayat di atas ialah, "Dan bertolongtolonglah kamu pada kebaikan dan takwa dan janganlah kamu bertolong-tolangan pada dosa dan permusuhan", adalah kebalikan dari paad berbuat aniaya. Setelah dilarang menganiaya, diperintahkan untuk melakukan birr(kebaikan).

\subsection{Pembiayaan Murabahah}

Murabahah adalah akad jual beli barang dengan harga jual sebesar biaya perolehan ditambah keuntungan yang disepakati dan penjual harus mengungkapkan biaya perolehan barang tersebut kepada pembeli. Sama halnya dengan fatwa yang dikeluarkan dewan syariah nasional majelis ulama indonesia NO:111/DSN-MUI/IX/2017, murabahah yaitu akad jual beli suatu barang dengan menegaskan harga belinya kapada pembeli dan pembeli membayar dengan harga lebih sebagai laba. Sangat berbeda dengan praktik riba dimana nasabah meminjam uang sejumlah tertentu untuk membeli

5 Kementrian Agama RI, Syaamil Al-Qur'an dan Terjemahannya,(Cet I; Bandung: Syaamil Cipta Media, 2005) suatu barang kemudian atas pinjaman tersebut nasabah harus membayar kelebihannya dan inilah riba

\subsection{Pembiayaan Musyarakah}

Musyarakah adalah akad kerja sama antara dua pihak atau lebih untuk suatu usaha tertentu, yaitu masing-masing pihak member kontribusi dana berdasarkan kesepakatan bahwa keuntungan dan resiko akan ditanggung bersama sesuai dengan aqad. Sementara itu dalam fatwa dewan syariah nasional majelis ulama indonesia No:133/DSN-MUI/X/2019,mendefinisikan musyarakah sebagai akad kerja sama antara dua pihak atau lebih untuk suatu usaha tertentu, dimana setiap pihak memberikan kontribusi modal untuk disatukan memjadi modal usaha bersama, dengan ketentuan bahwa keuntungan dibagi sesuai nisbah secara proporsional.

\subsection{Nilai Perusahaan}

Nilai perusahaan didefinisikan sebagai nilai pasar karena nilai perusahaan dapat memberikan kemakmuran pemegang saham secara maksimum apabila harga saham perusahaan meningkat. Jika kita melihat perusahaan bidang jasa dan barang yang dulunya kecil, kini semakin berkembang dan mengalami kemajuan yang pesat. Dulunya yang masih sektor usaha, kini menjadi sektor besar. 6 Berbagai kebijakan yang diambil oleh manajemen dalam upaya untuk meningkatkan nilai perusahaan melalui peningkatan kemakmuran pemilik dan pemegang saham yang tercermin pada harga saham ${ }^{7}$. Sedangkan rasio penilaian yang di gunakan untuk mengukur perusahaan terdiri dari Earning Per Share

${ }^{6}$ Afni, N., \& Jalil, A. (2021). Peran Pendidikan Akuntansi Dalam Masyarakat. Jurnal Ilmu Perbankan dan Keuangan Syariah, 3(1), 2

${ }^{7}$ Brigham E.F, \& Houstan. (2011). Dasar Dasar Manajemen Keuangan. Edisis 11 Buku 2. Salemba Empat. Jakarta 
(EPS), Price Earning Rtion (PER) atau rasio harga laba, dan Price Book Value $(P B V)^{8}$.

\subsection{Profitabilitas}

Profitabilitas merupakan rasio yang menggambarkan kemampuan perusahaan dalam menghasilkan laba ${ }^{9}$. Rasio profitabilitas merupakan rasio untuk menilai kemampuan perusahaan dalam mencari keuntungan. Nilai perusahaan dapat di pengaruhi oleh besar kecilnya profitabilitas ${ }^{10}$. Secara umum terdapat empat jenis utama yang digunakan dalam menilai tingkat profitabilitas meliputi Profit Margin (Profit Margin on Sales), Return on Investment (ROI), dan Return on Equity $(\mathrm{ROE})^{11}$.

\subsection{Kerangka Pemikiran}

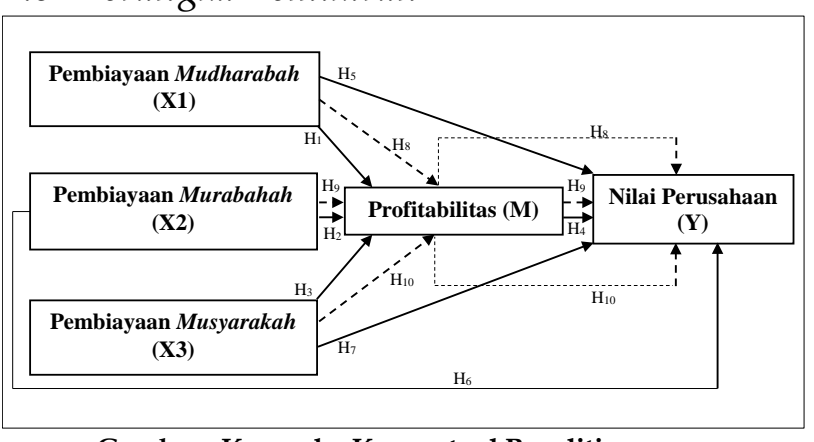

Gambar : Kerangka Konseptual Penelitian

Keterangan:

$\longrightarrow$ : Pengaruh interaksi masing-masing variabel independen terhadap variabel dependen dan variabel intervening.

$\boldsymbol{-} \rightarrow$ : Pengaruh interaksi masing-masing variabel independen terhadap variabel dependen melalui variabel intervening.

8 Fahmi. (2015). Manajemen Investasi, Teori Dan Soal Jawab. Edisi Kedua. Salemba Empat. Jakarta.

${ }^{9}$ Hary. (2015). Analisis Laporan Keuangan. Edisi Ke Satu. Centor For Academic Publising Services. Yogyakarta

${ }^{10}$ Analisa, Y. (2011). Pengaruh Ukuran Perusahaan, Leverage, Profitabilitas Dan Kebijakan Dividen Terhadap Nilai Perusahaan (Studi Pada Perusahaan Manufaktur Yang Terdaftar Di Bursa Efek Indonesia Tahun 2006-2008)

11 Kasmir. (2014). Analisis Laporan Keuangan. Edisi Pertama. Cetakan Ketujuh. Pt Raja Grafindo Persada.

\section{METHODOLOGY}

Metode yang digunakan dalam peneltian ini adalah metode kuantitatf dengan desain penelitian deskriptif verifikatif sedangkan sumber data dalam penelitian ini adalah data sekunder dan teknik analisis yang digunakan untuk pengujian hipotesis adalah teknik analisis jalur (path analysis).

Adapun sampel yang digunakan dalam penelitian ini adalah Bank Umum Syariah yang ada di Kota Palu

Tabel 1

Daftar Sampel Penelitian

\begin{tabular}{|c|l|c|}
\hline No & Bank Umum Syariah & $\begin{array}{c}\text { Kode } \\
\text { Perusahaan }\end{array}$ \\
\hline 1 & PT. Bank Muamalat Indonesia & BMI \\
\hline 2 & PT. Bank BRISyariah (Bank Syariah Indonesia, Tbk) & BRIS (BSI) \\
\hline 3 & PT. Bank BNI Syariah (Bank Syariah Indonesia, Tbk) & BNIS (BSI) \\
\hline 4 & PT. Bank Syariah Mandiri (Bank Syariah Indonesia, Tbk) & BSM (BSI) \\
\hline 5 & PT. Bank Syariah Bukopin & BSB \\
\hline
\end{tabular}

Sumber: Data diolah (2021)

\section{HASIL DAN PEMBAHASAN}

4.1 Analisis Statistik Deskriptif

Tabel 3

Statistik Deskriptif

\begin{tabular}{|l|c|c|c|}
\hline \multicolumn{1}{|c|}{ Variabel } & Minimal & Maksimal & Rata-Rata \\
\hline Profitabilitas & $0,1 \%$ & $17.7 \%$ & $6,2 \%$ \\
\hline Nilai Perusahaan & 0,06 & 238,6 & 41,31 \\
\hline Pembiayaan Mudharabah & 11,21 & 15,03 & 13,51 \\
\hline Pembiayaan Murabahah & 13,91 & 17,73 & 16,22 \\
\hline Pembiayaan Musyarakah & 13,65 & 17,17 & 16,55 \\
\hline
\end{tabular}

Berdasarkan tabel 3 menunjukan profitabilitas minimal $0,1 \%$ dan maksimal $17,7 \%$ dengan nilai rata-rata 6,2\%. Nilai perusahaan minimal 0,06 dan maksimal 238,6 dengan nilai rata-rata 41,31. Pembiayaan mudharabah minimal 11,21 dan maksimal 15,03 dengan nilai rata-rata 13,51. Pembiayaan murabahah minimal 13,91 dan maksimal 17,73 dengan nilai rata-rata 16,22. Pembiayaan musyarakah minimal 13,65 dan maksimal 17,17 dengan nilai rata-rata 16,55 . 
4.2 Hasil Analisis Asumsi Klasik

\subsubsection{Hasil Uji Normalitas}

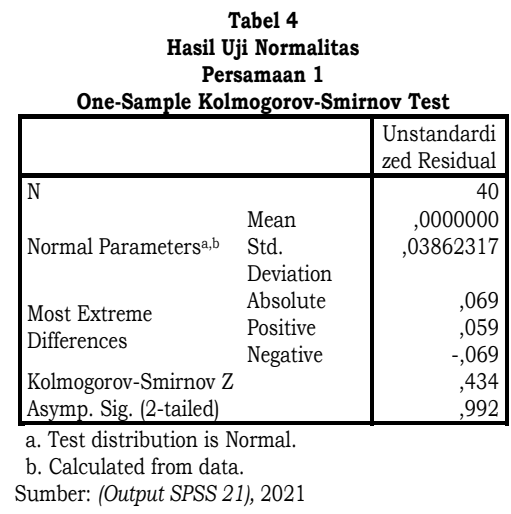

Berdasarkan output pada tabel 4 uji normalitas menunjukan bahwa nilai Asymp. Sig sebesar 0,992 > 0,05 maka persamaan 1 nilai residual terstandardisasi berdistribusi normal.

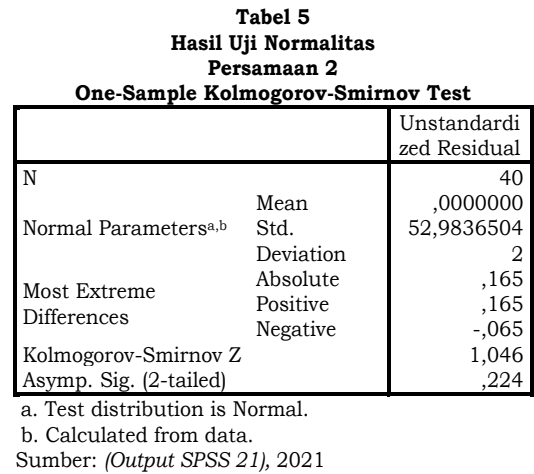

Berdasarkan output pada tabel 5 uji normalitas menunjukan bahwa nilai Asymp. Sig sebesar 0,224 > 0,05 maka persamaan 2 nilai residual terstandardisasi berdistribusi normal.

\subsubsection{Hasil Uji Multikolinearitas}

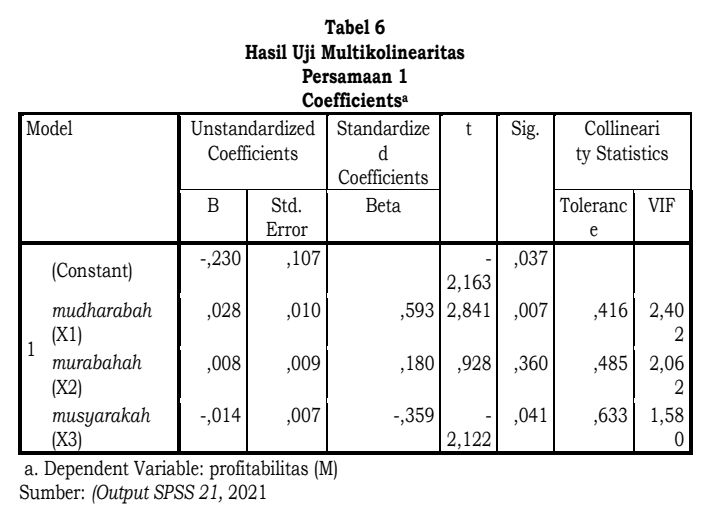

Berdasarkan output pada tabel 6 dengan melihat nilai tolerance variabel $\mathrm{X} 1, \mathrm{X} 2$, dan $\mathrm{X} 3>0,10$ dan nilai $\mathrm{VIF}<10,00$ sehingga dapat disimpulkan bahwa tidak terjadi multikolinearitas antar variabel independen dalam model regresi 1.

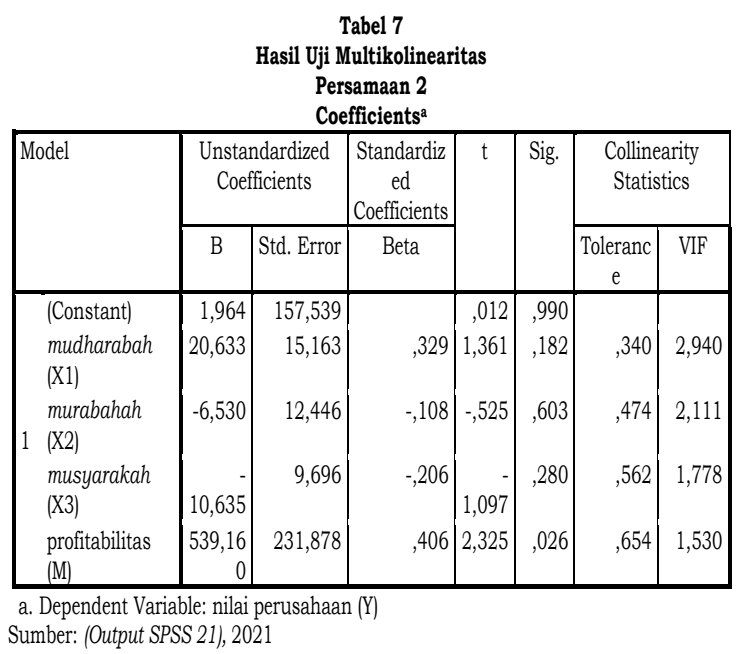

Berdasarkan output pada tabel 4.9, dengan melihat nilai tolerance variabel $\mathrm{X} 1, \mathrm{X} 2$, dan $\mathrm{X} 3>0,10$ dan nilai $\mathrm{VIF}<10,00$ sehingga dapat disimpulkan bahwa tidak terjadi multikolinearitas antar variabel independen dalam model regresi 2.

\subsubsection{Hasil Uji Autokorelasi}

Tabel 8

Hasil Uji Autokorelasi

Persamaan 1

Model Summary ${ }^{\mathrm{b}}$

\begin{tabular}{|l|c|r|r|r|r|}
\hline Model & $R$ & R Square & $\begin{array}{c}\text { Adjusted R } \\
\text { Square }\end{array}$ & $\begin{array}{r}\text { Std. Error of } \\
\text { the Estimate }\end{array}$ & $\begin{array}{r}\text { Durbin- } \\
\text { Watson }\end{array}$ \\
\hline 1 &, $588^{\mathrm{a}}$ &, 346 &, 292 &, 04020 & 1,627 \\
\hline
\end{tabular}

a. Predictors: (Constant), musyarakah (X3), murabahah (X2),

mudharabah (X1)

b. Dependent Variable: profitabilitas (M)

Sumber: (Output SPSS 21), 2021

Berdasarkan output pada tabel 8 menunjukan nilai DW sebesar 1,627 kemudian nilai $\mathrm{dl}=1,3348$ dan nilai $\mathrm{du}=1,6589$. Hasil nilai $4-\mathrm{du}=2,3411$ dan nilai 4-dl=2,6616. Berdasarkan hasil tersebut dapat disimpulkan bahwa terjadi korelasi sehingga terjadi autokorelasi pada persamaan 1. 
Tabel 9

Hasil Uji Autokorelasi

Persamaan 2

Model Summary

\begin{tabular}{|l|r|r|r|r|r|}
\hline Model & R & R Square & $\begin{array}{c}\text { Adjusted R } \\
\text { Square }\end{array}$ & $\begin{array}{r}\text { Std. Error of } \\
\text { the Estimate }\end{array}$ & $\begin{array}{l}\text { Durbin- } \\
\text { Watson }\end{array}$ \\
\hline 1 &, $550^{\mathrm{a}}$ &, 303 &, 223 & 55,92940 &, 578 \\
\hline
\end{tabular}

a. Predictors: (Constant), profitabilitas (M), musyarakah (X3), murabahah (X2), mudharabah (X1)

b. Dependent Variable: nilai perusahaan (Y)

Sumber: (Output SPSS 21), 2021

Berdasarkan output pada tabel 9 menunjukan nilai DW sebesar 0,578 kemudian nilai $\mathrm{dl}=1,2848$ dan nilai $\mathrm{du}=1,7209$. Hasil nilai $4-\mathrm{du}=2,2791$ dan nilai 4-dl=2,7152. Berdasarkan hasil tersebut dapat disimpulkan bahwa terjadi korelasi sehingga terjadi autokorelasi pada persamaan 2 .

\subsubsection{Hasil Uji Heterokedastisitas}

\begin{tabular}{|c|c|c|c|c|c|}
\hline & Hasil Uj & $\begin{array}{l}\text { Tabel } 10 \\
\text { i Heterosked } \\
\text { Persamaan } \\
\text { Coefficients }\end{array}$ & lastisitas & & \\
\hline \multirow[t]{2}{*}{ Model } & \multicolumn{2}{|c|}{$\begin{array}{c}\text { Unstandardized } \\
\text { Coefficients }\end{array}$} & $\begin{array}{c}\text { Standardized } \\
\text { Coefficients }\end{array}$ & \multirow[t]{2}{*}{$\mathrm{t}$} & \multirow[t]{2}{*}{ Sig. } \\
\hline & B & Std. Error & Beta & & \\
\hline \multirow{4}{*}{\begin{tabular}{|l} 
(Constant) \\
mudharabah \\
1 (X1) \\
murabahah (X2) \\
musyarakah \\
(X3)
\end{tabular}} &,- 092 & ,058 & & $-1,573$ & , 125 \\
\hline &,- 007 & ,005 &,- 304 & $-1,339$ & 189 \\
\hline & ,015 & , 005, & 662 & 3,141 & , 003, \\
\hline &,- 002 & ,004 &,- 094 &,- 507 & 615, \\
\hline
\end{tabular}

Berdasarkan output pada tabel 10 menunjukan nilai sig variabel $\mathrm{X} 2$ lebih kecil dari 0,05 maka sesuai dengan dasar pengambilan keputusan dalam uji heteroskedastisitas, persamaan 1 pada variabel X2 disimpulkan terjadi masalah heterokedastisitas.

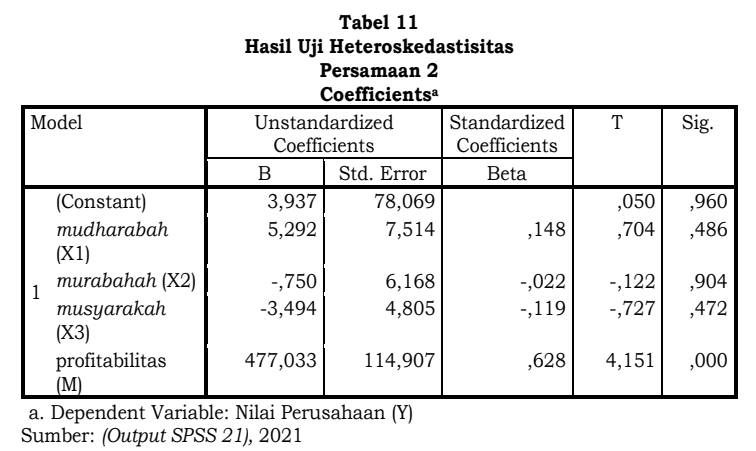

Berdasarkan output pada tabel 11 menunjukan nilai sig variabel $\mathrm{M}$ lebih kecil dari 0,05 maka sesuai dengan dasar pengambilan keputusan dalam uji heteroskedastisitas, persamaan 2 pada variabel $M$ disimpulkan terjadi masalah heterokedastisitas.

\subsection{Hasil Analisis Data Regresi Tabel 12 \\ Hasil Analisis Jalur \\ Persamaan Regresi 1}

\begin{tabular}{|c|c|c|c|c|c|}
\hline \multirow{3}{*}{ Model } & \multicolumn{3}{|c|}{ Coefficients $^{a}$} & \multirow{3}{*}{$\mathrm{t}$} & \multirow{3}{*}{ Sig. } \\
\hline & \multicolumn{2}{|c|}{$\begin{array}{l}\text { Unstandardized } \\
\text { Coefficients }\end{array}$} & $\begin{array}{c}\text { Standardized } \\
\text { Coefficients }\end{array}$ & & \\
\hline & $\mathrm{B}$ & Std. Error & Beta & & \\
\hline (Constant) &,- 230 & , 107 & & $\begin{array}{r}2,16 \\
3\end{array}$ & ,037 \\
\hline $\begin{array}{l}\text { mudharabah } \\
1 \text { (X1) }\end{array}$ & ,028 & ,010 &, 593 & $\begin{array}{r}2,84 \\
1\end{array}$ & ,007 \\
\hline murabahah (X2) & ,008 &, 009 & , 180 & ,928 & ,360 \\
\hline $\begin{array}{l}\text { musyarakah } \\
\text { (X3) }\end{array}$ &,- 014 & ,007 &,- 359 & $\begin{array}{r}- \\
2,12 \\
2\end{array}$ & ,041 \\
\hline
\end{tabular}

a. Dependent Variable: profitabilitas (M)

Sumber: (Output SPSS 21), 2021

\begin{tabular}{|c|c|c|c|c|c|}
\hline & $\begin{array}{l}\mathrm{Ha} \\
\text { Pers }\end{array}$ & $\begin{array}{l}\text { Tabel } 13 \\
\text { il Analisis J } \\
\text { amaan Regr } \\
\text { Coefficients }\end{array}$ & $\begin{array}{l}\text { alur } \\
\text { esi } 2 \\
\text { a }\end{array}$ & & \\
\hline \multirow[t]{2}{*}{ Model } & \multicolumn{2}{|c|}{$\begin{array}{l}\text { Unstandardized } \\
\text { Coefficients }\end{array}$} & \multirow{2}{*}{$\begin{array}{c}\begin{array}{c}\text { Standardized } \\
\text { Coefficients }\end{array} \\
\text { Beta }\end{array}$} & \multirow[t]{2}{*}{$\mathrm{t}$} & \multirow[t]{2}{*}{ Sig. } \\
\hline & B & Std. Error & & & \\
\hline (Constant) & 1,964 & 157,539 & & ,012 & ,990 \\
\hline $\begin{array}{l}\text { mudharabah } \\
\text { (X1) }\end{array}$ & 20,633 & 15,163 & ,329 & 1,361 & 182 \\
\hline \multirow{3}{*}{$\begin{array}{l}1 \text { murabahah (X2) } \\
\text { musyarakah } \\
\text { (X3) } \\
\text { profitabilitas } \\
\text { (M) }\end{array}$} & $-6,530$ & 12,446 &,- 108 &,- 525 & ,603 \\
\hline & $-10,635$ & 9,696 &,- 206 & $-1,097$ &, 280 \\
\hline & 539,160 & 231,878 & ,406 & 2,325 &, 026 \\
\hline
\end{tabular}

a. Dependent Variable: nilai perusahaan $(\mathrm{Y})$

Sumber: (Output SPSS 21), 2021

\subsection{Hasil Uji Parsial (Uji T)}

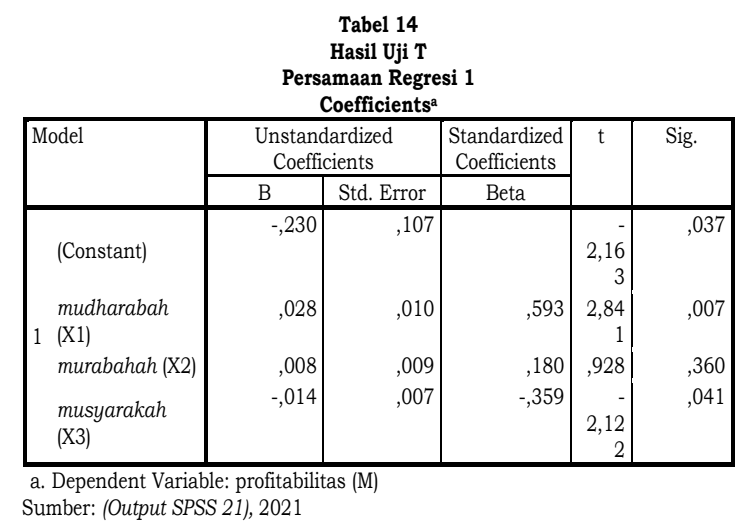

Berdasarkan Uji $\mathrm{T}$ pada tabel 14 menunjukan mudharabah diperoleh nilai thitung 2,814 dengan nilai signifikansinya lebih kecil dari taraf kepercayaan 5\% (0,007 
$>0,05)$. Murabahah diperoleh nilai thitung 0,928 dengan nilai signifikansinya lebih besar dari taraf kepercayaan 5\% (0,360 > 0,05). Musyarakah diperoleh nilai thitung 2,122 dengan nilai signifikansinya lebih kecil dari taraf kepercayaan 5\% $(0,041<$ $0,05)$.

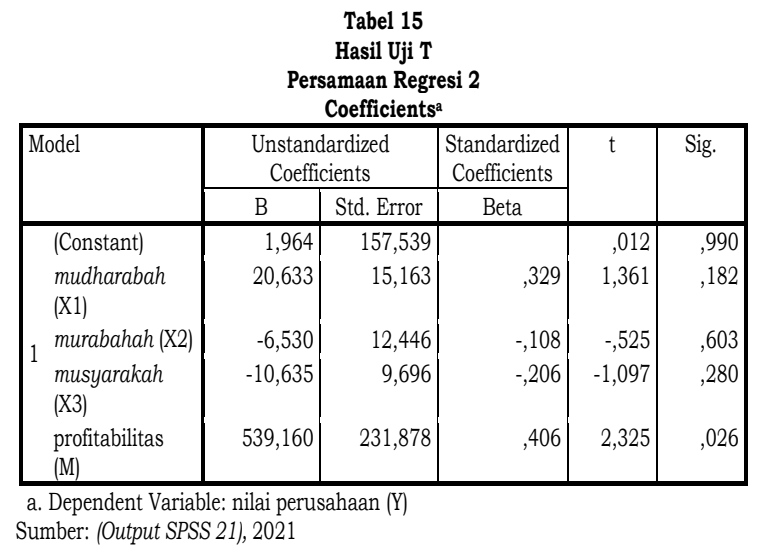

Berdasarkan Uji $\mathrm{T}$ pada tabel 15 menunjukan profitabilitas diperoleh nilai thitung 2,325 dengan nilai signifikansinya lebih kecil dari taraf kepercayaan 5\% (0,026 $<0,05)$. Mudharabah diperoleh nilai thitung 1,361 dengan nilai signifikansinya lebih besar dari taraf kepercayaan 5\% (0,182 > 0,05). Murabahah diperoleh nilai thitung 0,525 dengan nilai signifikansinya lebih besar dari taraf kepercayaan 5\% (0,603 > 0,05). Musyarakah diperoleh nilai thitung 1,097 dengan nilai signifikansinya lebih besar dari taraf kepercayaan 5\% (0,280 > $0,05)$.

\subsection{Hasil Uji Sobel (Sobel Test)}

$X 1 \sqrt{(539,160 \times 0,010)^{2}+(0,028 \times 231,878)^{2}+(0,010 \times 231,878)^{2}}$
$\sqrt{29,069+42,153+5,376}$
$\sqrt{76,598}$
$s a b=8,752$
$a b=539,160 \times 0,240$
thitung $=\frac{a b}{s a b}$
$14,813=\frac{129,398}{8,752}$

Berdasarkan sobel tes di atas dapat diketahui nilai thitung sebesar 14,784 sedangkan ttabel pada signifikansi sebesar 2,021 sehingga thitung $>$ ttabel $(14,784>2,021)$.

$\times 2 \sqrt{(539,160 \times 0,009)^{2}+(0,008 \times 231,878)^{2}+(0,009 \times 231,878)^{2}}$

$\sqrt{23,546+3,441+4,355}$

$\sqrt{31,342}$

$s a b=5,598$

$a b=539,160 \times 0,073$

thitung $=\frac{a b}{s a b}$

$7,030=\frac{39,358}{5,598}$

Berdasarkan sobel tes di atas dapat diketahui nilai thitung sebesar 7.030 sedangkan ttabel pada signifikansi sebesar 2,021 sehingga thitung $>$ ttabel $(7,030>2,021)$.

$X 3 \sqrt{(539,160 \times 00,007)^{2}+(-0,014 \times 231,878)^{2}+(0,007 \times 231,878)^{2}}$

$$
\begin{aligned}
& \sqrt{14,243+10,538+2,634} \\
& \sqrt{27,415} \\
& s a b=5,235 \\
& a b=539,160 x-0,145 \\
& \text { thitung }=\frac{a b}{\text { sab }} \\
& -14,933=\frac{-78,178}{5,235}
\end{aligned}
$$

Berdasarkan sobel tes di atas dapat diketahui nilai thitung sebesar -14,933 sedangkan ttabel pada signifikansi sebesar 2,021 sehingga thitung < ttabel ($14,933<2,021$ ) 


\subsection{Pembahasan}

\subsubsection{Pengaruh Pembiayaan Mudharabah terhadap Profitabilitas}

Berdasarkan hasil pengujian hipotesis menunjukan bahwa pembiayaan mudhabahah berpengaruh signifikan terhadap profitabilitas bank umum syariah di Indonesia. Mudharabah merupakan pembiayaan yang didasarkan pada prinsip bagi hasil. Hasil analisis menunjukan bahwa adanya pengaruh positif pembiayaan mudharabah terhadap profitabilitas yang berarti semakin besar pembiayaan mudharabah maka semakin tinggi profitabilitas bank umum syariah.

\subsubsection{Pengaruh Pembiayaan Murabahah terhadap Profitabilitas}

Berdasarkan hasil pengujian hipotesis menunjukan bahwa pembiayaan murabahah tidak berpengaruh signifikan terhadap profitabilitas bank umum syariah di Indonesia. Hasil analisis menunjukan bahwa tidak adanya pengaruh pembiayaan murabahah terhadap profitabilitas yang berarti semakin besar pembiayaan murabahah tidak mempengaruhi profitabilitas bank umum syariah. Murabahah merupakan pembiayaan yang didasarkan pada prinsip jual beli.

\subsubsection{Pengaruh Pembiayaan Musyarakah terhadap Profitabilitas}

Berdasarkan hasil pengujian hipotesis menunjukan bahwa pembiayaan musyarakah berpengaruh signifikan terhadap profitabilitas bank umum syariah di Indonesia. Musyaarakah merupakan pembiayaan yang didasarkan pada prinsip bagi hasil. Hasil analisis menunjukan bahwa adanya pengaruh negatif pembiayaan musyarakah terhadap profitabilitas yang berarti semakin besar pembiayaan musyarakah maka semakin mengurangi profitabilitas bank umum syariah.

\subsubsection{Pengaruh Profitabilitas Terhadap Nilai Perusahaan}

Berdasarkan hasil pengujian hipotesis menunjukan bahwa profitabilitas berpengaruh terhadap nilai perusahaan. Profitabilitas merupakan kemampuan perusahaan dalam mendapatkan keuntungan. Hasil analisis menunjukan bahwa adanya pengaruh positif profitabilitas terhadap nilai perusahaan yang berarti semakin tinggi profitabilitas maka semakin meningkatkan nilai perusahaan pada bank umum syariah.

\subsubsection{Pengaruh Pembiayaan Mudharabah Terhadap Nilai Perusahaan}

Berdasarkan hasil pengujian hipotesis menunjukan bahwa pembiayaan mudharabah tidak berpengaruh signifikan terhadap nilai perusahaan pada bank umum syariah di Indonesia. Hasil analisis menunjukan bahwa tidak adanya pengaruh pembiayaan mudharabah terhadap nilai perusahaan yang berarti besar kecilnya pembiayaan mudharabah tidak mempengaruhi nilai perusahaan pada bank umum syariah.

\subsubsection{Pengaruh Pembiayaan Murabahah Terhadap Nilai Perusahaan}

Berdasarkan hasil pengujian hipotesis menunjukan bahwa pembiayaan murabahah tidak berpengaruh signifikan terhadap nilai perusahaan pada bank umum syariah di Indonesia. Hasil analisis menunjukan bahwa tidak adanya pengaruh pembiayaan murabahah terhadap nilai perusahaan yang berarti fluktuasi pembiayaan murabahah tidak mempengaruhi nilai perusahaan pada bank umum syariah 


\subsubsection{Pengaruh Pembiayaan Musyarakah Terhadap Nilai Perusahaan}

Berdasarkan hasil pengujian hipotesis menunjukan bahwa pembiayaan musyarakah tidak berpengaruh signifikan terhadap nilai perusahaan pada bank umum syariah di Indonesia. Hasil analisis menunjukan bahwa tidak adanya pengaruh signifikan pembiayaan musyarakah terhadap nilai perusahaan yang berarti fluktuasi pembiayaan musyarakah tidak mempengaruhi nilai perusahaan pada bank umum syariah.

4.6.8 Pengaruh Pembiayaan Mudharabah

Terhadap Nilai Perusahaan melalui Profitabilitas

Hasil pengujian hipotesis menunjukan bahwa pembiayaan mudhabahah berpengaruh signifikan terhadap nilai perusahaan melalui profitabilitas bank umum syariah di Indonesia. Hasil analisis menunjukan bahwa adanya pengaruh signifikan pembiayaan mudharabah terhadap nilai perusahaan melalui profitabilitas yang berarti semakin besar pembiayaan mudharabah maka semakin tinggi profitabilitas sehingga meningkatkan nilai perusahaan bank umum syariah.

\subsubsection{Pengaruh Pembiayaan Murabahah Terhadap Nilai Perusahaan melalui Profitabilitas}

Hasil pengujian hipotesis menunjukan bahwa pembiayaan murabahah berpengaruh terhadap nilai perusahaan melalui profitabilitas bank umum syariah di Indonesia. Hasil analisis menunjukan bahwa adanya pengaruh signifikan pembiayaan murabahah terhadap nilai perusahaan melalui profitabilitas yang berarti semakin besar pembiayaan murabahah maka semakin tinggi profitabilitas sehingga meningkatkan nilai perusaan bank umum syariah.
4.6.10 Pengaruh Pembiayaan Musyarakah Terhadap Nilai Perusahaan melalui Profitabilitas

Hasil pengujian hipotesis menunjukan bahwa pembiayaan musyarakah tidak berpengaruh signifikan terhadap nilai perusahaan melalui profitabilitas bank umum syariah di Indonesia. Hasil analisis menunjukan bahwa tidak adanya pengaruh signifikan pembiayaan musyarakah terhadap nilai perusahaan melalui profitabilitas yang berarti semakin besar pembiayaan musyarakah maka tidak mempengaruhi profitabilitas dan nilai perusaan bank umum syariah.

\section{KESIMPULAN DAN SARAN}

5.1 Kesimpulan

Pengaruh pembiayaan mudharabah dan musyarakah terhadap profitabilitas sementara pembiyaan murabahah tidak berpengaruh terhadap profitabilitas. Sedangkan profitabilitas berpengaruh terhadap nilai perusahaan sedangkan pembiyaan mudharabah, murabahah, musyarakah tidak berpengaruh terhadap nilai perusahaan. Pembiayaan mudharabah dan murabahah memiliki pengaruh terhadap nilai perusahaan melalui profitabilitas dan pembiayaan musyarakah tidak memiliki pengaruh terhadap nilai perusahaan melalui perofitabilitas.

\subsection{Saran}

Peneliti berikutnya dengan konsentrasi syariah dapat menggunkan variabel dengan pengukuran islamic social reporting index, islamic investment atau zakat performance ratio untuk memperluas objek penelitian kemudian bagi Bank Umum Syariah (BUS) yang terdaftar pada Otoritas Jasa Keungan (OJK) dan Bank Indonesia (BI) dapat mensosialisasikan resiko pembiayaan bermasalah dan pelatihan 
keterampilan dalam melakukan analisis maupun struktur fasilitas yang di berikan untuk mengurangi tingkat pembiayaan bermasalah atau non performing financing.

\section{DAFTAR PUSTAKA}

Analisa, Y. (2011). Pengaruh Ukuran Perusahaan, Leverage, Profitabilitas Dan Kebijakan Dividen Terhadap Nilai Perusahaan (Studi Pada Perusahaan Manufaktur Yang Terdaftar Di Bursa Efek Indonesia Tahun 2006-2008)

Afni, N., \& Jalil, A. (2021). PERAN PENDIDIKAN AKUNTANSI DALAM MASYARAKAT. Jurnal Ilmu Perbankan dan Keuangan Syariah, 3(1), 1-15.

Brigham E.F, \& Houstan. (2011). DasarDasar Manajemen Keuangan. Edisis 11 Buku 2. Salemba Empat. Jakarta
Fahmi. (2015). Manajemen Investasi, Teori Dan Soal Jawab. Edisi Kedua. Salemba Empat. Jakarta.

Hary. (2015). Analisis Laporan Keuangan. Edisi Ke Satu. Centor For Academic Publising Services. Yogyakarta

Jalil, A., \& Hamzah, S. A. (2020). PENGARUH BAGI HASIL DAN KEBUTUHAN MODAL TERHADAP MINAT UMKM MENGAJUKAN PEMBIAYAAN PADA LEMBAGA KEUANGAN SYARIAH DI KOTA PALU. Jurnal Ilmu Perbankan dan Keuangan Syariah, 2(2), 178-198.

Kementrian Agama RI, Syaamil Al-Qur'an dan Terjemahannya,(Cet I; Bandung: Syaamil Cipta Media,2005)

Kasmir. (2014). Analisis Laporan Keuangan. Edisi Pertama. Cetakan Ketujuh. Pt Raja Grafindo Persada 